\title{
Efficacy of $\mathrm{CaCl}_{2}$ against some important postharvest fungi on orange, chilli and Cavendish banana fruits
}

\author{
Hiệu quả của $\mathrm{CaCl}_{2}$ đối với một số loại nấm quan trọng gây hại sau thu hoạch trên trái cam, \\ ớt và chuối già
}

LE, Thanh Toan*; VO, Trong Ky; NGUYEN, Thi My Linh; TRIEU, Phuong Linh; NGO, Van Toan; NGUYEN, Huy Hoang

College of Agriculture and Applied Biology, Can Tho University, 3/2 Str., Can Tho city, Viet Nam

\begin{abstract}
Fruit rot caused by Aspergillus niger or Colletotrichum musae is an important post-harvest disease on orange, chilli and Cavendish banana fruits. The use of synthetic fungicides has been a traditional strategy for the management of the fruit rot disease, but these chemicals adversely affect human health and environment. Therefore, the objective of this study was to evaluate the effects of $\mathrm{CaCl}_{2}$ on in vitro hyphal growth and in vivo lesion inhibition. First, aqueous solutions of $\mathrm{CaCl}_{2}$ at three concentrations of 20,40 and $60 \mathrm{mM}$ were assessed for their inhibitory effect against hyphal growth in vitro. Next, mature fruits were immersed into a solution of $20 \mathrm{mM} \mathrm{CaCl} 2$ for $20-30 \mathrm{~s}$, then inoculated by a pathogen suspension at the density of $10^{6}$ conidia $\mathrm{mL}^{-1}$ and observed for 12 days. The results showed that $20 \mathrm{mM} \mathrm{CaCl}_{2}$ was the most effective concentration in antifungal assay to Aspergillus isolated from orange rot. The treatment of $\mathrm{CaCl}_{2}$ continued to gain efficacy on limiting lesions' development on orange fruits until 12 days after inoculation (DAl). On chilli, $\mathrm{CaCl}_{2}$ at concentrations of 20 and $40 \mathrm{mM}$ inhibited well on the growth of Aspergillus hyphae isolated from chilli rot. However, calcium treatment was not effective on chilli fruits. On Cavendish banana, solutions of $\mathrm{CaCl}_{2}$ at concentrations of 20,40 and $60 \mathrm{mM}$ highly limited fungal growth of Colletotrichum in vitro conditions. The application of $\mathrm{CaCl}_{2}$ solution could inhibit anthracnose lesion length of Cavendish banana variety, but its efficacy did not prolong until 6 DAl. In general, the good results were obtained from the $20 \mathrm{mM} \mathrm{CaCl}_{2}$ in almost all the studied assays. Management of rot diseases on fruits by employing $20 \mathrm{mM} \mathrm{CaCl}_{2}$ could be suitable to replace the current hazardous agro-chemicals.
\end{abstract}

Thối trái do nấm Aspergillus niger hay nấm Colletotrichum musae là bệnh sau thu hoạch thường gặp trên cam, ớt và chuối già. Thuốc trừ nấm tổng hợp là biện pháp truyền thống quản lý bệnh thối trái nhưng lại ảnh hưởng bất lợi đến sức khỏe con người và môi trường. Vi vậy, muc tiêu của nghiên cứu là đáng giá ảnh hưởng của $\mathrm{CaCl}_{2}$ đối với sự sinh trưởng in vitro của nấm và sự ức chế vết bệnh ở điều kiện in vivo. Đầu tiên, dung dịch $\mathrm{CaCl}_{2}$ ở các nồng độ 20,40 và 60 mM được sử dụng để đánh giá khả năng ức chế sự sinh trưởng in vitro của nấm bệnh. Tiếp theo, trái trưởng thành được nhúng vào dung dịch $\mathrm{CaCl}_{2} 20 \mathrm{mM}$ trong 20 - 30 s, rồi lây nhiễm với huyền phù mầm bệnh ở mật số $10^{6}$ bào tử $\mathrm{mL}^{-1}$ và quan sát đến 12 ngày. Kết quả cho thấy $\mathrm{CaCl}_{2} 20 \mathrm{mM}$ có hiệu quả ức chế tốt đối với nấm Aspergillus phân lập từ bệnh thối trái cam. $\mathrm{CaCl}_{2}$ tiếp tục thể hiện hiệu quả ức chế bệnh trên trái cam đến 12 ngày sau lây bệnh. Trên ớt, $\mathrm{CaCl}_{2} 20$ và $40 \mathrm{mM}$ cho hiệu quả ức chế sự phát triển nấm Aspergillus phân lập từ bệnh thối trái ớt. Tuy nhiên, xử lý CaCl 2 không mang lại hiệu quả mong đợi trên trái ớt. Trên chuối già, dung dịch $\mathrm{CaCl}_{2}$ ở các nồng độ 20, 40 và 60 mM ức chế tốt sợi nấm Colletotrichum trong điều kiện in vitro. Dung dịch canxi có thể ức chế vết bệnh thán thư trên chuối già, nhưng hiệu quả không kéo dài đến 6 ngày sau lây bệnh. Nhìn chung, các kết quả tốt đều đạt được khi xử lý bằng $\mathrm{CaCl}_{2} 20$ mM ở hầu hết các thí nghiệm. Việc kiểm soát bệnh thối trái bằng $\mathrm{CaCl}_{2} 20$ mM có thể thay thế cho hóa chất nông nghiệp độc hại hiện nay.

Keywords: Aspergillus niger, Colletotrichum musae, hyphal development, lesion inhibition

\section{Introduction}

The world fruit and vegetable production has quickly increased several folds over the last decades, applies to many kinds of the major crops including orange, chilli, banana, cucurbits, tomato, and cabbage, according to FAO reports (FAO, 2008). The rapid production of fruit and vegetable has occurred for several reasons. Nutritional and medicinal researches elucidate the value and role of these foods in protecting human health. Fruits and vegetables provide essential nutrients as: carbohydrates, vitamins, minerals and fibres. Moreover, the current active global market and internationally intense import/export businesses make it possible for fresh agricultural products which cultivate in one part of the world to be quickly shipped and available to consumers anywhere else in the world. Increased production and business agreements always place a high pressure on farmers that they cannot 
allow diseases to affect their harvest products. Fruit rot caused by Aspergillus niger Tiegh. or Colletotrichum musae (Berk. \& Curtis) Arx. is the most important post-harvest disease on fruits (Sarkar, 2016; Dashora and Sharma, 2018; Lema et al., 2018). Average post-harvest losses to these fungi have been estimated at approximately $20 \%$ at developed countries, and up to 50\% at developing countries (Janisiewicz and Korsten, 2002; Florkowski et al., 2009).

In Viet Nam, despite several advances of the production and disease management on fruits and vegetables, farmers often face many challenges (Hue and Nghiem, 2014). Fruit rot caused by $A$. niger plays a major role on losses of orange and chilli production from fields to storage houses (Long, 2012; Xuyen, 2012). A niger also causes rot diseases on other fruits and vegetables such as mango, lemon, grapefruit, onion and garlic (Hocking, 2006; Liaquat et al., 2016). This fungi species not only cracks and causes damage on fruit epidermis but also secretes aflatoxins, a group of harmfully carcinogenic mycotoxins. These toxic compounds are heat-stable and are non-degradable by a variety of food processing procedures. Especially, low-level exposure to aflatoxins may lead to a suppression of the immune system and increase susceptibility to diseases in humans (Pestka and Bondy, 1994). In banana, anthracnose caused by $C$. musae, usually produces black and brown spots on banana peels, leading to low price and severe economic losses (Lassois et al., 2010). Furthermore, C. musae was reported as the popular post-harvest pathogenic fungus in Cavendish bananas in Viet Nam (Hang, 2012).

Many strategies are available for managing pathogens in fresh agricultural products. On the first strategy, application of waxes to fruit surfaces was researched. Waxing could improve the fruit appearance, reduces spoilage due to chilling injury, decreases the respiration and transpiration rates and protects fruit epidermis against infection by fungal pathogens. However, waxes could not improve the quality of fruits. Another major disadvantage of using wax for coating the fruits is the development of off-flavor (Sharma and Singh, 2000). In another strategy, UV-C light was applied for managing diseases on fruits and vegetables. The optimum dose and the time required to achieve maximum protection after UV-C treatment against plant pathogens vary depending on the nature of products (D'hallewin et al., 1999). Besides, fruit diseases could be managed using beneficial pathogens. Thanh et al. (2016) indicated that beneficial Streptomyces fradiae and Bacillus polyfermenticus were capable of inhibiting fungal growth of Neoscytalidium dimitiatum causing brown spot disease on dragon fruits in Vietnam. Efficacy of heat treatments and other disease management strategies has also been assessed (Palou et al., 2001; Awang et al., 2011; Mahmud et al., 2008; Ayon-Reyna et al., 2017; Netravati and Jagadeesh, 2018). The efficacy of different heat procedures (aqueous immersion of oranges in: water at up to $75^{\circ} \mathrm{C}$ for $150 \mathrm{~s} ; 2$ $4 \%$ sodium carbonate aqueous solution at $45^{\circ} \mathrm{C}$ for 60 $150 \mathrm{~s}$, or $1-4 \%$ sodium bicarbonate aqueous solution at room temperature for $150 \mathrm{~s}$ followed by storage at $20^{\circ} \mathrm{C}$ for 7 days) was determined in order to control blue mold disease of oranges caused by Penicillium italicum. The incidence of green mold caused by $P$. digitatum was reduced to approximately $1-12 \%$, whereas the untreated fruits were entirely (100\%) infected by green mold disease (Palou et al., 2001). Last but not least, calcium treatments have been reported to retain fruit firmness in various agricultural products, including apple (Conway et al., 1994), custard apple (Netravati and Jagadeesh, 2018), peach (Manganaris et al., 2007; Sohail et al., 2015; Gayed et al., 2017), persimmon (Bagheri et al., 2015), pomegranate (Mirdehghan and Ghotbi, 2014), blackberry (Turmanidze et al., 2016), cape gooseberry (Reyes-Medina et al., 2017), tomato (Arthur et al., 2015) and lemon (Valero et al., 1998). Soaking the dragon fruits for 40 min in solutions of $\mathrm{CaCl}_{2}$ significantly increased the fruit Ca content in the fruit peels, leading to reduce the size of anthracnose lesions (Awang et al., 2011). In mango, solutions containing various concentrations of $\mathrm{CaCl}_{2}$ could delay the fruit ripening (Mahmud et al., 2008). However, the values of flavors and taste of the mango fruits at ripening were 4.0, 3.0, 2.5 and 2.25 at 2.5, 5.0, 7.5 and $10 \% \mathrm{CaCl}_{2}$, respectively. Treatment of $\mathrm{CaCl}_{2}$ or combination of hot water - $\mathrm{CaCl}_{2}$ could reduce mycelial growth and germination of C. gloeosporioides in vitro as well as delay anthracnose symptom on papaya fruits (Madani et al., 2016; Ayon-Reyna et al., 2017). In addition, $\mathrm{CaCl}_{2}$ at a concentration of $4 \%$ could reduce the severity of infection from different fungi including Alternaria alternata, Alternaria solani, A. niger, Botrytis cinerea, Fusarium solani and Rhizopus stolonifer on guava fruits (Hassanein et al., 2018). On calcium treated-fruits, the association between firmness retention and reduced rot incidence suggests that calcium might affect both these processes simultaneously through its cellular role in strengthening fruit cell walls (Fallahi et al., 1997; Conway et al., 1999). The major advantage of calcium treatment on fruits is the safety to human health and avoidance of environmental pollutions.

Current researches on preventing Aspergillus fruit rot on orange and chilli fruits, as well as anthracnose on Cavendish banana fruits have not been carried out with $\mathrm{CaCl}_{2}$ yet. Therefore, the objective of this study was to assess the efficacy of $\mathrm{CaCl}_{2}$ treatment on growth of hyphae and on the diameter of rot lesions on fruits.

\section{Materials and methods}

\subsection{Materials}

\subsubsection{Fungal strains and culturing}

Two samples of virulent strains of $A$. niger isolated from orange and chilli fruits, and one virulent strain of C. musae isolated from banana anthracnose lesions were cultivated at Department of Plant Protection, College of Agriculture and Applied Biology, Can Tho University. The fungi A. niger and C. musae were isolated from infected fruits and identified by molecular analysis (Hang, 2012; Long, 2012; Xuyen, 2012). The fungi were prepared on Potato Dextrose Agar 
(PDA) at pH 6.5 at about 10-12 days before conducting experiments. Medium of PDA was prepared followed the procedure of Atlas (2004). The fungi were incubated at $28 \pm 2$ ${ }^{\circ} \mathrm{C}$ with relative humidity approximately $90 \%$.

\subsubsection{Chemicals}

$\mathrm{CaCl}_{2} 2 \mathrm{H}_{2} \mathrm{O}$ (Catalogue No. 1023820500, purity $\geq 95 \%$, Merck, Germany) was provided from Department of Plant Protection, Can Tho University.

Prior to this research, different concentrations of $\mathrm{CaCl}_{2} 2 \mathrm{H}_{2} \mathrm{O}$ had been quickly screened to evaluate their effects on spore germination of $A$. niger and C. musae. Subsequently, $\mathrm{CaCl}_{2} 2 \mathrm{H}_{2} \mathrm{O}$ at 20, 40 and $60 \mathrm{mM}$ were chosen for this research because it gave the high efficacy in inhibiting spore germination.

\subsection{Assessment of $\mathrm{CaCl}_{2}$-efficacy on hyphal development of post-harvest fungi in vitro conditions}

The experiments were carried out in completely randomized design (CRD), with four treatments including $\mathrm{CaCl}_{2}$ at three different concentrations (20,40, and $60 \mathrm{mM}$ ), and a water control treatment with six replications, one petri dish for each replication. Separated experiment was done with A. niger isolated from orange and chilli fruits, with C. musae of banana anthracnose. Experimental steps conducted were followed the procedure of Dhinggra and Sinclair (1995), Mahmud et al. (2008), and Hajano et al. (2012).

The aqueous solutions of $\mathrm{CaCl}_{2}$ was prepared according to treatment above description. To assure complete solubility, each sample of aqueous $\mathrm{CaCl}_{2}$ was magnetically stirred for $30 \mathrm{~min}$. The $\mathrm{CaCl}_{2}$ solutions were filtered through Whatman papers with pore size of approximately $0.2 \mu \mathrm{m}$. The filtered solutions were then poured into the medium of PDA at $55-60{ }^{\circ} \mathrm{C}$ for 2 min and gently shaken. Approximately $10 \mathrm{~mL}$ of each obtained mixture medium was immediately poured into Petri dishes. After media solidification, a hyphal round slice of fungi at approximately $5 \mathrm{~mm}$ diameter was placed at in the center of each petri dish (Dhinggra and Sinclair, 1995). Diameter of fungal colony was measured at 48, 72 and 96 hours for experiments with A. niger, and at 24, 48 and 72 hours for C. musae.

Each experiment was performed 3 times. Based on results of in vitro experiments, an effective concentration of $20 \mathrm{mM}$ of $\mathrm{CaCl}_{2}$ was chosen to conduct following experiments on orange, chilli and Cavendish banana fruits.

\subsection{Assessment of treating $\mathrm{CaCl}_{2}$ at an effective concentration on fruits before inoculation with fungal suspension}

The experiment was done in CRD with two treatments including $\mathrm{CaCl}_{2}$-treated and control treatments, with 12 replications, one fruit per one replication, four inoculated points per one orange fruit, one inoculated point per one chilli or banana fruit.

Experimental fruits including orange, chilli and Cavendish banana were chosen, and surface-disinfected with 95\% ethanol ( $v / v$ ) for one min, and washed two times with sterile distilled water to remove the alcohol residue. Next, the fruits were immersed in a solution of $\mathrm{CaCl}_{2}$ for 20-30s, then, air-dried for 1-2 h at room temperature. On the untreated control, the fruits were handled identically, but sterile distilled water was used instead of $\mathrm{CaCl}_{2}$ solution. After that, a bunch of sterile needles was used to create tiny holes with a depth of $2 \mathrm{~mm}$ on fruit epidermis, with four positions on orange fruits, one position on chilli or Cavendish banana fruits. One $\mathrm{mL}$ of fungal spore suspension at a density of $10^{6}$ conidia $\mathrm{mL}^{-1}$ was dropped on these tiny holes.

Inoculated fruits were stored in an incubation chamber at $25^{\circ} \mathrm{C}$ with relative humidity approximately $98 \%$ for $24 \mathrm{~h}$. Finally, inoculated fruits were transferred into transparent nylong bags with wet cotton inside, at room temperature (Sivakumar et al., 2002; Cao et al., 2008; Talibi et al., 2011; Yu et al., 2012) to observe the disease symptoms.

Length of Aspergillus rot lesions was recorded at 8, 10 and 12 days after inoculation (DAI) (on orange fruits), 4, 6 and 8 DAI (on chilli fruits). Separated experiment on orange or chilli fruits was repeated three times.

Anthracnose lesions length on banana fruits were recorded at 5, 6 and 7 DAl (De Costa and Erabadupitiya, 2005). The experiment was done twice.

\subsection{Statistical analysis}

Data were subjected to an analysis of variance using SPSS 16.0 software package (IBM, USA). Individual comparisons between mean values were performed using Duncan's Multiple Range Test (DMRT) or t-test with a magnitude of $p$ value at 0.05 .

\section{Results and discussion}

\subsection{Effect of $\mathrm{CaCl}_{2}$ solutions against Aspergillus niger on orange fruits}

\subsubsection{Efficacy of $\mathrm{CaCl}_{2}$ on Aspergillus hyphal development in vitro}

Each tested concentration of $\mathrm{CaCl}_{2}$ showed different fungal activity in vitro conditions (Table 1 and Figure 1). Results for the individual concentration varied during three observation time points. The optimal efficacy was observed using 
the treatment with as solution of $20 \mathrm{mM} \mathrm{CaCl}_{2}$. Colonial diameter of the treatment of $20 \mathrm{mM} \mathrm{CaCl}_{2}$ was $78.2 \mathrm{~mm}$, significantly lower than that of the control sample $(85.3 \mathrm{~mm})$ at 96 hours adding putting fungal slices.

Table 1. Efficacy of $\mathrm{CaCl}_{2}$ on colonial diameter ( $\mathrm{mm}$ ) of Aspergillus niger in vitro

Treatment Time after adding fungal slices (hours)

$48^{1 /} \quad 72^{1 /} \quad 96^{1 /}$

\begin{tabular}{|c|c|c|c|}
\hline $\begin{array}{l}20 \mathrm{mM} \\
\mathrm{CaCl}_{2} 2 \mathrm{H}_{2} \mathrm{O}\end{array}$ & $40.7 \pm 5.8^{c}$ & $61.4 \pm 7.2^{c}$ & $78.2 \pm 6.9^{b}$ \\
\hline $\begin{array}{l}40 \mathrm{mM} \\
\mathrm{CaCl}_{2} 2 \mathrm{H}_{2} \mathrm{O}\end{array}$ & $48.0 \pm 6.1^{b}$ & $70.8 \pm 7.1^{b}$ & $88.0 \pm 6.4^{a}$ \\
\hline $\begin{array}{l}60 \mathrm{mM} \\
\mathrm{CaCl}_{2} 2 \mathrm{H}_{2} \mathrm{O}\end{array}$ & $56.1 \pm 6.3^{a}$ & $77.8 \pm 7.4^{a}$ & $84.5 \pm 7.2^{a}$ \\
\hline Water control & $42.8 \pm 5.6^{c}$ & $70.3 \pm 6.5^{b}$ & $85.3 \pm 7.3^{a}$ \\
\hline Significance & * & * & $\star$ \\
\hline $\begin{array}{l}\text { Coefficient of } \\
\text { variance (\%) }\end{array}$ & 7.26 & 5.38 & 5.41 \\
\hline
\end{tabular}

"Mean \pm SE (standard error) followed by the same letter do not differ significantly according to DMRT at $p \leq 0.05$.

*: significant at $p \leq 0.05$

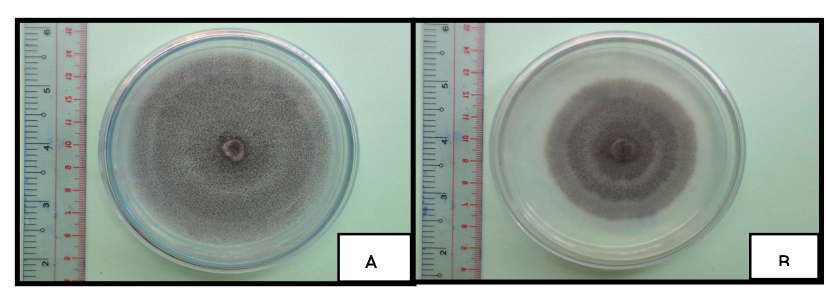

Figure 1. Efficacy of $20 \mathrm{mM} \mathrm{CaCl}_{2}$ on the growth of Aspergillus niger at 96 hours after putting fungal slices.

The round slice of Aspergillus was put at the center of a Petri dish containing PDA medium and solution of $\mathrm{CaCl}_{2}$ or distilled water. A: The control treatment with distilled water, B: the solution of $\mathrm{CaCl}_{2}$ at a concentration of $20 \mathrm{mM}$.

3.1.2 Efficacy of treating $\mathrm{CaCl}_{2}$ on oranges before an inoculation of Aspergillus suspension

Disease incidence on orange fruits was 100\% (data not shown). The effect of $\mathrm{CaCl}_{2}$ was assessed on the length of rot lesion on orange fruits at three observation time points. The lesion length of calcium treatment was significantly lower than that of the control at 8 DAl, and prolonged until 12 DAl (Table 2 and Figure 2).

The orange fruits were immersed on a solution of $20 \mathrm{mM}$ $\mathrm{CaCl}_{2}$ first, made tiny holes on orange epidermis at four positions by sterile needles, then inoculated with Aspergillus spore suspension at a density of $10^{6}$ conidia $\mathrm{mL}^{-1}$. Control: the orange fruit was treated with sterile distilled water, $\mathrm{CaCl}_{2} 20 \mathrm{mM}$ : the orange fruit was treated with $\mathrm{CaCl}_{2}$-solution at a concentration of $20 \mathrm{mM}$.
Table 2. Efficacy of $\mathrm{CaCl}_{2}$ treated before Aspergillus inoculation on orange fruits

Treatment Days after inoculation

$8^{1 /} \quad 10^{1 /} \quad 12^{1 /}$

$20 \mathrm{mM} \quad 81.92 \pm 19.6^{\mathrm{b}} \quad 96.17 \pm 17.3^{\mathrm{b}} \quad 127.83 \pm 18.2^{\mathrm{b}}$

$\mathrm{CaCl}_{2} \cdot 2 \mathrm{H}_{2} \mathrm{O}$

Non-treated $105.5 \pm 19.8^{\mathrm{a}} \quad 131.17 \pm 15.3^{\mathrm{a}} 161.00 \pm 15.3^{\mathrm{a}}$ control

Significance

Coefficient of

27.99

27.17

21.57

variance (\%)

\footnotetext{
"Mean \pm SE (standard error) followed by the same letter do not differ significantly according to DMRT at $p \leq 0.05$.

*: significant at $p \leq 0.05$
}

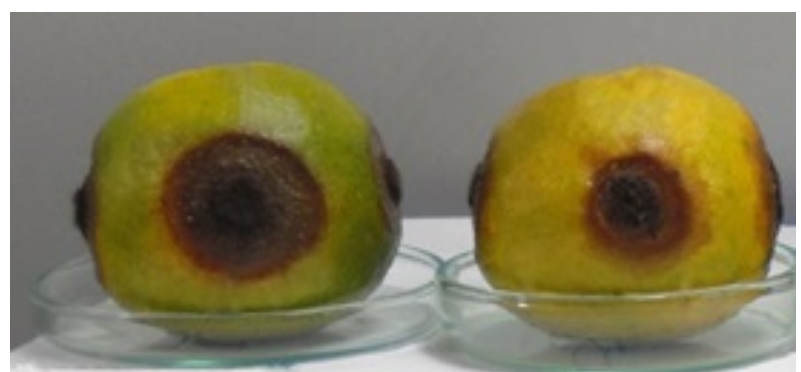

A

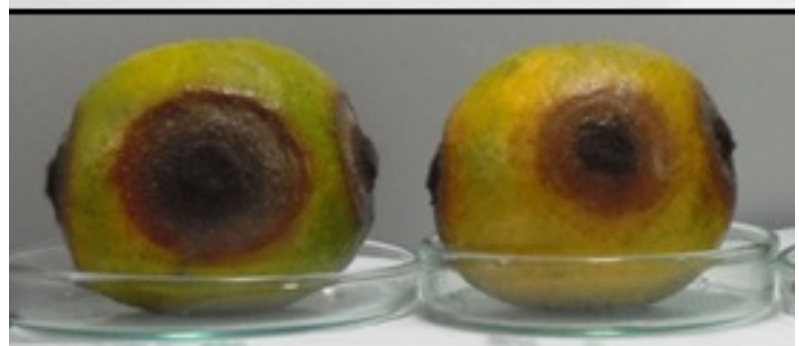

B

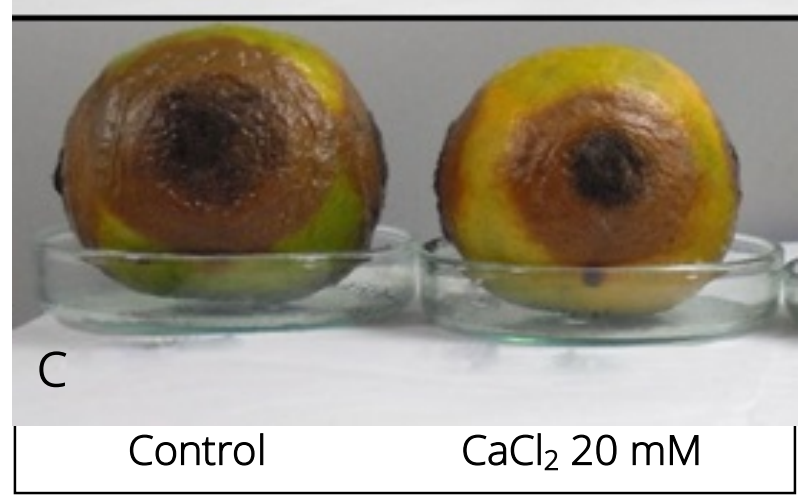

Figure 2. Efficacy of $\mathrm{CaCl}_{2}$ at a concentration of $20 \mathrm{mM}$ on rot lesions caused by Aspergillus niger at $8 \mathrm{DAI}(\mathrm{A}), 10 \mathrm{DAl}(\mathrm{B}), 12$ DAI (C).

\subsection{Effect of $\mathrm{CaCl}_{2}$ solutions against Aspergillus niger on chilli fruits}

3.2.1 Efficacy of $\mathrm{CaCl}_{2}$ on Aspergillus hyphal development in vitro 
The results showed that calcium treatment at a concentration of $20 \mathrm{mM} \mathrm{CaCl}_{2}$ inhibited hyphal development of $\mathrm{A}$. niger during all observation time points. The treatment of 20 $\mathrm{mM} \mathrm{CaCl} 2$ had ability from 48 to 96 hours after putting fungal slices, while $\mathrm{CaCl}_{2}$ at a concentration of $60 \mathrm{mM}$ was effective on 72 and 96 hours after putting fungal slice. Therefore, the concentration at $20 \mathrm{mM}$ of $\mathrm{CaCl}_{2}$ showed a high and stable efficacy than other treatments, and was chosen to do on the following experiment (Table 3).

Table 3. Efficacy of $\mathrm{CaCl}_{2}$ on colonial diameter (mm) of Aspergillus niger in vitro

\begin{tabular}{|c|c|c|c|}
\hline \multirow[t]{2}{*}{ Treatment } & \multicolumn{3}{|c|}{ Time after adding fungal slices (hours) } \\
\hline & $48^{1 /}$ & $72^{1 /}$ & $96^{1 /}$ \\
\hline $\begin{array}{l}20 \mathrm{mM} \\
\mathrm{CaCl}_{2} \cdot 2 \mathrm{H}_{2} \mathrm{O}\end{array}$ & $36.80 \pm 4.5^{b}$ & $52.50 \pm 6.1^{b}$ & $58.20 \pm 6.2^{b}$ \\
\hline $\begin{array}{l}40 \mathrm{mM} \\
\mathrm{CaCl}_{2} 2 \mathrm{H}_{2} \mathrm{O}\end{array}$ & $40.50 \pm 5.1^{a}$ & $54.00 \pm 5.8^{b}$ & $62.80 \pm 7.2^{b}$ \\
\hline $\begin{array}{l}60 \mathrm{mM} \\
\mathrm{CaCl}_{2} \cdot 2 \mathrm{H}_{2} \mathrm{O}\end{array}$ & $42.00 \pm 5.3^{a}$ & $59.80 \pm 5.2^{a}$ & $74.00 \pm 7.1^{a}$ \\
\hline Water control & $41.20 \pm 4.6^{a}$ & $57.50 \pm 5.4^{a}$ & $75.50 \pm 8.2^{a}$ \\
\hline Significance & * & * & * \\
\hline $\begin{array}{l}\text { Coefficient of } \\
\text { variance (\%) }\end{array}$ & $7.82 \%$ & $5.85 \%$ & $10.32 \%$ \\
\hline $\begin{array}{l}\text { "Mean } \pm \text { SE } \\
\text { not differ sig } \\
\text { *: significant }\end{array}$ & $\begin{array}{l}\text { andard error) } \\
\text { cantly accordi } \\
p \leq 0.05\end{array}$ & $\begin{array}{l}\text { llowed by the s } \\
\text { to DMRT at p }\end{array}$ & $\begin{array}{l}\text { ame letter do } \\
\leq 0.05\end{array}$ \\
\hline
\end{tabular}

\subsubsection{Efficacy of treating $\mathrm{CaCl}_{2}$ on chilli before an inoculation of Aspergillus suspension}

Treatment of $\mathrm{CaCl}_{2}$ at a concentration of $20 \mathrm{mM}$ did not inhibit Aspergillus rot lesion on chilli fruits (Table 4).

Table 4. Efficacy of $\mathrm{CaCl}_{2}$ treated before Aspergillus inoculation on chilli fruits

Treatment Days after inoculation

$4^{1 /} \quad 6^{1 /} \quad 8^{1 /}$

$\begin{array}{lccc}20 \mathrm{mM} & 13.51 \pm 0.23 & 17.33 \pm 0.32 & 20.58 \pm 0.24 \\ \mathrm{CaCl}_{2} 2 \mathrm{H}_{2} \mathrm{O} & & & \\ \begin{array}{l}\text { Non-treated } \\ \text { control }\end{array} & 10.34 \pm 0.19 & 16.76 \pm 0.33 & 19.02 \pm 0.27 \\ \begin{array}{l}\text { Significance } \\ \text { Coefficient of }\end{array} & \mathrm{ns} & \mathrm{ns} & \mathrm{ns} \\ \text { variance (\%) } & 15.47 \% & 21.78 \% & 17.59 \%\end{array}$

"Mean \pm SE (standard error) followed by the same letter do not differ significantly according to DMRT at $P=0.05$.

*: significant at $p \leq 0.05$; ns: non-significant at $p \leq 0.05$

\subsection{Effect of $\mathrm{CaCl}_{2}$ solutions against} Colletotrichum musae on Cavendish banana fruits

\subsubsection{Efficacy of $\mathrm{CaCl}_{2}$ on Colletotrichum hyphal} development in vitro

Efficacy of $\mathrm{CaCl}_{2}$ was determined by colonial diameters of Colletotrichum musae during three observation time points at 24, 48 and 72 hours after in vitro culture. At the time point of $24 \mathrm{~h}$, all treatments of three concentrations of $\mathrm{CaCl}_{2}$ had small colonies ranged from $8.66 \mathrm{~mm}$ to 10.00 $\mathrm{mm}$, significantly lower than that of the control treatment of approximately $12.50 \mathrm{~mm}$. At two following observation time points of 48 and $72 \mathrm{~h}$, only $\mathrm{CaCl}_{2}$ at a concentration of $20 \mathrm{mM}$ was effective on inhibiting development of Colletotrichum colony, compared to those of control one (Table 5).

Table 5. Colonial diameter ( $\mathrm{mm}$ ) of Colletotrichum musae in vitro condition

Treatment Time after adding fungal slices (hours)

$\begin{array}{lccc} & 24^{1 /} & 48^{1 /} & 72^{1 /} \\ 20 \mathrm{mM} & 8.66 \pm 2.3^{\mathrm{c}} & 29.67 \pm 4.5^{\mathrm{b}} & 58.50 \pm 12.1^{\mathrm{c}} \\ \mathrm{CaCl} 22 \mathrm{H}_{2} \mathrm{O} & & & \\ 40 \mathrm{mM} & 10.00 \pm 2.7^{\mathrm{b}} & 33.83 \pm 4.8^{\mathrm{a}} & 63.67 \pm 11.3^{\mathrm{a}} \\ \mathrm{CaCl} \cdot 2 \mathrm{H}_{2} \mathrm{O} & & & \\ 60 \mathrm{mM} & 9.17 \pm 1.9^{\mathrm{bc}} & 34.33 \pm 5.2^{\mathrm{a}} & 63.17 \pm 9.3^{\mathrm{ab}} \\ \mathrm{CaCl}_{2} 2 \mathrm{H}_{2} \mathrm{O} & & & \\ \text { Water control } & 12.50 \pm 1.8^{\mathrm{a}} & 34.00 \pm 5.7^{\mathrm{a}} & 60.00 \pm 11.2^{\mathrm{b}} \\ \text { Significance } & * & * & * \\ \text { Coefficient of } & 12.41 & 5.63 & 5.79 \\ \text { variance (\%) } & & & \end{array}$

"Mean \pm SE (standard error) followed by the same letter do not differ significantly according to DMRT at $p \leq 0.05$.

*: significant at $p \leq 0.05$

The effective concentration of $\mathrm{CaCl}_{2}$ at $20 \mathrm{mM}$ was chosen to carry out assays on Cavendish banana fruits.

\subsubsection{Efficacy of treating $\mathrm{CaCl}_{2}$ on Cavendish bananas before an inoculation of Colletotrichum}

Lesion lengths of $\mathrm{CaCl}_{2}$-treatment were short at approximately $11.92 \mathrm{~mm}$, and statistically significant to those of control at $13.00 \mathrm{~mm}$ at $5 \mathrm{DAl}$. However, efficacy of $\mathrm{CaCl}_{2}$ did not prolong to 6 and 7 DAl (Table 6 and Figure 3).

Table 6. Efficacy of $\mathrm{CaCl}_{2}$ treated before Colletotrichum inoculation on Cavendish banana fruits

Treatment

Days after inoculation

\begin{tabular}{|c|c|c|c|}
\hline $\begin{array}{l}20 \mathrm{mM} \\
\mathrm{CaCl}_{2} \cdot 2 \mathrm{H}_{2} \mathrm{O}\end{array}$ & $11.92 \pm 3.4^{b}$ & $17.42 \pm 3.5$ & $23.67 \pm 4.2$ \\
\hline $\begin{array}{l}\text { Non-treated } \\
\text { control }\end{array}$ & $13.00 \pm 3.6^{a}$ & $18.25 \pm 3.2$ & $25.08 \pm 3.8$ \\
\hline Significance & * & ns & ns \\
\hline $\begin{array}{l}\text { Coefficient of } \\
\text { variance (\%) }\end{array}$ & 11.12 & 12.22 & 11.53 \\
\hline
\end{tabular}


"Mean \pm SE (standard error) followed by the same letter do not differ significantly according to DMRT at $p \leq 0.05$; *: significant at $p \leq 0.05$; ns: non-significant at $p \leq 0.05$
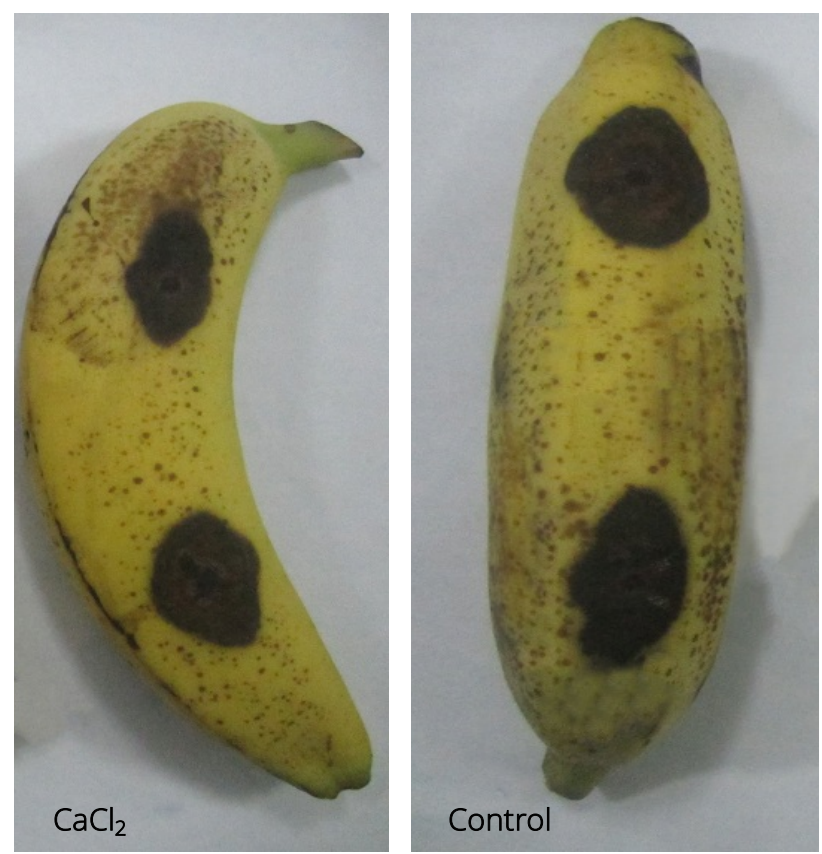

Figure 3. Efficacy of $\mathrm{CaCl}_{2}$ treatment before Colletotrichum inoculation on Cavendish bananas at 7 DAI.

The banana fruits of Cavendish were immersed on a solution of $20 \mathrm{mM} \mathrm{CaCl}_{2}$ at approximately 20 s, air-dried for 2 h. Tiny holes were created by sterile needles with a depth of $2 \mathrm{~mm}$ on banana epidermis. One $\mathrm{mL}$ of Colletotrichum spore suspension at a density of $10^{6}$ conidia $\mathrm{mL}^{-1}$ was dropped on these tiny holes. $\mathrm{CaCl}_{2}$ : the banana fruit was treated with $\mathrm{CaCl}_{2}$ at a concentration of $20 \mathrm{mM}$, Control: the banana fruit was treated with distilled water.

\section{Discussion}

At in vitro conditions, the results showed that $20 \mathrm{mM} \mathrm{CaCl}$ significantly inhibited the growth of the pathogenic fungi $A$. niger and C. musae, better than $\mathrm{CaCl}_{2}$ solutions at 40 and $60 \mathrm{mM}$. Calcium solution at an optimal concentration was required for the inhibition of hyphae, whereas low or high concentrations could non-effect on hyphal growth. Fungal cells exposed to the optimal concentration increased their calcium level in the cytosol, leading to alter the osmotic balance and be toxic to the fungal cells (Al-Eryani-Raqeeb et al., 2009). The cell walls of fungal pathogens were rich in neutral sugars. When a low concentration of $\mathrm{CaCl}_{2}$ was applied in vitro conditions, exogenous $\mathrm{Ca}^{2+}$ stimulated a production of glucosamine, a kind of amino sugars. The glucosamine is beneficial to fungal growth, resulted in failure on fungal inhibition. On the contrary, high calcium concentration reduced neutral sugars, but lead to an increase in uronic acid, $\mathrm{Ca}, \mathrm{P}$ and $\mathrm{Na}$ in fungal cytosol. Uronic acid is a part of fungal cell walls. Besides, elements of $\mathrm{Ca}, \mathrm{P}$ and $\mathrm{Na}$ play important roles in metabolism and energy transfer as well as an integral component of DNA, RNA, coenzymes and membrane phospholipids of fungal cells. Therefore, fungal pathogens could grow in the PDA medium containing a high calcium concentration (Chardonnet et al., 1999; Stosic et al., 2014).

At in vivo conditions, the results showed that treatment of $20 \mathrm{mM} \mathrm{CaCl}_{2}$ on orange, chilli and Cavendish banana reduced the lesions length. The reduction of rot symptom in $\mathrm{CaCl}_{2}$-treated fruits could be due to calcium content of fruit peels and host-pathogen interaction. On fruits, calcium is mainly associated with the pectic materials. The $\mathrm{Ca}^{2+}$ ions could interact with the anionic pectic polysaccharides, coordinating with the oxygen functions of two adjacent pectin chains, and cross-linking the chains (Rose et al., 2003). The calcium binding could reduce the accessibility of cell wall degrading enzymes from Aspergillus fungus to the substrates of fruits. In the research of Marcelle (1995), the authors indicated that calcium treatment could conserve fruit epidermis, inhibit a post-harvest respiratory peak and delay the ripen process of apple fruits. Moreover, $\mathrm{CaCl}_{2}$ could be treated at 2-3 weeks before harvesting, leading to prolong shelf life of fruit (Sen et al., 2001). On mango and strawberry fruits, soaking or dipping fruits into the solution of $\mathrm{CaCl}_{2}$ lead to decrease fruit rot (Uthaibutra et al., 1998; Lara et al., 2004). On red-flesh dragon fruits, $\mathrm{CaCl}_{2}$ applied at various concentrations at 1, 2, 3 and $4 \mathrm{gL}^{-1}$ reduced the anthracnose severity. The concentration of $\mathrm{CaCl} 2$ at $4 \mathrm{gL}^{-1}$ (approximately $27 \mathrm{mM}$ ) gave the best inhibition on anthracnose lesions (Awang et al., 2011). Our results of 20 $\mathrm{mM} \mathrm{CaCl}_{2}$ on this study are in line to results of Awang et al. (2011). Similarly, $\mathrm{CaCl}_{2}$ was reported to inhibit the in vitro development of C. gloeosporioides in papaya fruits (AyonReyna et al., 2017). In a recent study, Hassanein et al. (2018) indicated that $4 \%$ (w/v) $\mathrm{CaCl}_{2}$ could use with gramma irradication to inhibit fungal growth of $A$. alternate, A. solani, A. niger, B. cinerea, F. solani and R. stolonifer on guava fruits.

Moreover, host-pathogen interaction on $\mathrm{CaCl}_{2}$-treated fruits could be an important mechanism. The fungal pathogen must first attack the fruit skin, where fungus secretes cell wall degrading enzymes, favouring the fungal infection (Chardonnet et al., 1999). However, the strengthening of the fruit cell walls by $\mathrm{Ca}^{2+}$ binding the polygalacturonase, reduce the susceptibility to fungal infection (Rose et al., 2003), leading to slow the development of rot lesions on $\mathrm{CaCl}_{2}$-treated fruits. In general, $\mathrm{CaCl}_{2}$ application in adequate amounts supplied helps to maintain orange, chilli and banana fruits' firmness, decrease on an incidence of fungal attack, leading to limit the diameter of rot lesions.

\section{Conclusion}

The concentration at $20 \mathrm{mM}$ of $\mathrm{CaCl}_{2}$ well inhibited the hyphal development of both $A$. niger and C. musae in vitro. However, this concentration of $\mathrm{CaCl}_{2}$ was effective on inhibiting Aspergillus rot lesion only on orange fruits in vivo conditions. However, a treatment of $20 \mathrm{mM} \mathrm{CaCl}_{2}$ on chilli or Cavendish banana fruits had a lower efficacy than on orange fruits. The immersion of orange fruits in a solution 
of $20 \mathrm{mM}$ might be a useful strategy to control fruit rot. Future studies are needed to formulate a commercial solution of $\mathrm{CaCl}_{2}$.

\section{References}

[1] Al-Eryani-Raqeeb, A., Mahmud, T.M.M., Omar, S.R.S., Zaki, A.R.M., Al-Eryani, A.R. 2009. Effects of calcium and chitosan treatments on controlling anthracnose and post-harvest quality of papaya (Carica papaya L.). International Journal of Agricultural Research 4: 5368.

[2] Arthur, E., Oduro, I., Kumah, P. 2015. Postharvest quality response of tomato (Lycopersicon esculentum Mill.) fruits to different concentrations of calcium chloride at different dip-times. American Journal of Food and Nutrition 5(1): 1-8.

[3] Atlas, R.M. 2004. Handbook of microbiological media, $3^{\text {rd }}$ edition. CRC Press Boca Raton London New York Washington, D.C., USA. 2051p.

[4] Ayon-Reyna, L.E., Lopez-Valenzuela, J.A., Delgado-Vargas, F., Lopez-Lopez, M.E., Molina-Corral, F.J., CarrilloLopez, A., Vega-Garcia, M.O. 2017. Effect of the combination hot water - calcium chloride on the in vitro growth of Colletotrichum gloeosporioides and the postharvest quality of infected papaya. The Plant Pathology Journal 33(6): 572-581.

[5] Awang, Y., Ghani, M.A.A., Sijam, K., Mohamad, R.B. 2011. Effect of calcium chloride on anthracnose disease and postharvest quality of red-flesh dragon fruits (Hylocereus polyrhizus). African Journal of Microbiology Research 5(29): 5250-5259.

[6] Bagheri, M., Esna-Ashari, M., Ershadi, A. 2015. Effect of postharvest calcium chloride treatment on the storage life and quality of persimmon fruits (Diopyros kaki Thunb.) cv. 'Karaij'. International Journal of Horticultural Science and Technology 2(1): 15-26.

[7] Cao, S., Zheng, Y., Yang, Z., Tang, S., Jin, P., Wang, K., Wang, X. 2008. Effects of methyl jasmonate on the inhibition of Colletotrichum acutatum infection in loquat fruit and the possible mechanisms. Postharvest Biology and Technology 49: 301-307.

[8] Chardonnet, C.O., Sams, C.E., Conway, W.S. 1999. Calcium effect on the mycelial cell walls of Botrytis cinerea. Phytochemistry 52: 967-973.

[9] Conway, W.S., Janisiewicz, W.J., Klein, J.D., Sams, C.E. 1999. Strategy for combining heat treatment, calcium infiltration, and biocontrol to reduce postharvest decay of "Gala" apples. HortScience 34: 700-704.

[10] Conway, W.S., Sams, C.E., Wang, C.Y., Abbott, J.A. 1994. Additive effects of postharvest calcium and heat treatment on reducing decay and maintaining quality in apples. Journal of the American Society for Horticultural Science 119: 49-53.
[11] D'hallewin, G., Schirra, M., Manueddu, E., Piga, A., BenYehoshua, S. 1999. Scoparone and scopoletin accumulation and ultraviolet- $C$ induced resistance to postharvest decay in oranges as influenced by harvest date. Journal of the American Society for Horticultural Science 124: 702-707.

[12] Dashora, A., Sharma, K. 2018. Isolation of fungal species from infected chilli fruit and their identification. World Journal of Pharmacy and Pharmaceutical Sciences 7(8): 1146-1159.

[13] De Costa, D.M., Erabadupitiya, H.R.U.T. 2005. An integrated method to control postharvest diseases of banana using a member of the Burkholderia cepacia complex. Postharvest Biology and Technology 36: 31 39.

[14] Dhinggra, O.D., Sinclair, J.B. 1995. Basic plant pathology methods, $2^{\text {nd }}$ edition. CRC Press. 434p.

[15] Fallahi, E., Conway, W.S., Hickey, K.D., Sams, C.E. 1997. The role of calcium and nitrogen in postharvest quality and disease resistance of apples. HortScience 32: 831-835.

[16] FAO (Food and Agriculture Organization of the United Nations). 2008. FAOStat. Retrieved from http://www.fao.org/faostat.

[17] Florkowski, W.J, Shewfelt, R., Brueckner, B., Prussia, S.E. 2009. Postharvest handling - A systems approach. Academic Press, 30 Corporate Drive, Suite 400, Burlington, MA 01803, USA. 615p.

[18] Gayed, A.A.N.A., Shaarawi, S.A.M.A, Elkhishen, M.A., Elsherbini, N.R.M. 2017. Pre-harvest application of calcium chloride and chitosan on fruit quality and storability of 'Early Swelling' peach during cold storage. Ciencia e Agrotecnologia 41(2): 220-223.

[19] Hajano, J., Lodhi, A.M., Pathan, M.A., Khanzada, M.A., Shah, G.S. 2012. In-vitro evaluation of fungicides, plant extracts and bio-controlagents against rice blast pathogen Magnaporthe oryzae Couch. Pakistan Journal Botany 44(5): 1775-1778.

[20] Hang, L.T.T. 2012. Diagnosis of post-harvest fungal pathogens on banana fruits (Musa sapientum L.). Thesis in Plant Protection. Can Tho University. 50p.

[21] Hassanein, R.A., Salem, E.A., Zahran, A.A. 2018. Efficacy of coupling gamma irradiation with calcium chloride and lemongrass oil in maintaining guava fruit quality and inhibiting fungal growth during cold storage. Folia Horticulture 30(1): 67-78.

[22] Hocking, A.D. 2006. Aspergillus and related teleomorphs. In: Food spoilage microorganisms, Blackburn, C. de W. (Ed). Woodhead Publishing Ltd., Cambridge CB1 6AH, UK. pp 451-487.

[23] Hue, N.T., Nghiem, H.D. 2014. Research on the status of chemical pesticide uses in agricultural activities in Phan Me commune, Phu Luong district, Thai Nguyen province. Journal of Vietnamese Environment 6(2): 
$138-141$

[24] Janisiewicz, W.J., Korsten, L. 2002. Biological control of postharvest diseases of fruits. Annual Review of Phytopathology 40: 411-441.

[25] Lara, I., Garcisa, P., Vendrell, M. 2004. Modification in cell wall componsion calcium-trested strawbery (Fragaria $x$ ananassa Duch) fruit. Postharvest Biology and Technology 34: 331-39.

[26] Lassois, L., Jijakli, M.H., Chillet, M., De Bellair, L. 2010. Crow rot of bananas. Preharvest factor involved in postharvest disease development and integrated control methods. Plant Disease 94(6): 648-658.

[27] Lema, A.A., Mudansiru, A., Alexander, B.A., Sakinatu, M.J. 2018. Evaluation of fungal species isolated from three different varieties of pepper (Capsicum chinense, C. frutescens and C. annum L.) in Dutsin-ma, Katsina State. Annals of Biological Sciences 6(1): 13-17.

[28] Liaquat, F., Arif, S., Ashraf, M., Chaudhary, H.J., Munis, M.F. 2016. Aspergillus niger causes fruit rot of lemon and grapefruit in Pakistan. Plant Disease 100(9): p1951.

[29] Long, P.P. 2012. Diagnosis of post-harvest fungal pathogens in chilli (Capsicum spp.) fruits. Thesis in Plant Protection. Can Tho University. 59p.

[30] Madani, B., Mirshekari, A., Sofo, A., Mohamed, M.T.M. 2016. Preharvest calcium applications improve postharvest quality of papaya fruits (Carica papaya L. CV. Eksotika II). Journal of Plant Nutrition 39(10): 1483 1492.

[31] Mahmud, T.M.M., Kadir, J., Rahman, R.A., Begum, M.M 2008. Antimicrobial activities of chitosan and canxi chloride on in vitro growth of Colletotrichum g/oeosporioides from papaya. Pertanika Journal of Tropical Agricultural Science 31(2): 223-232.

[32] Manganaris, G.A., Vasilakakis, M., Diamantidis, G., Mignani, I. 2007. The effect of postharvest calcium application on tissue calcium concentration, quality attributes, incidence of flesh browning and cell wall physicochemical aspects of peach fruits. Food Chemistry 100: 1385-1392.

[33] Marcelle, D.R. 1995. Mineral nutrition and fruit quality. Acta-Hortculturae 383: 219-225.

[34] Mirdehghan, S.H., Ghotbi, F. 2014. Effects of salicylic acid, jasmonic acid, and calcium chloride on reducing chilling injury of pomegranate (Punica granatum L.) fruit. Journal of Agricultural Science and Technology 16: 163-173

[35] Netravati, Suresh, G.J., Jagadeesh, S.L. 2018. Calcium chloride and wax influences the post harvest behaviour of custard apple fruits. Journal of Pharmacognosy and Phytochemistry 7(2): 79-84.

[36] Palou, L., Smilanick, J.L., Usall, J., Viñas, I. 2001. Control of postharvest blue and green molds of oranges by hot water sodium carbonate and sodium bicarbonate. Plant Disease 85: 371-376.

[37] Pestka, J.J., Bondy, G.S. 1994. Mycotoxin-induced immune modulation. In: Immunotoxicology and immunopharmacology, Dean, J.H., Luster, M.I., Munson, A.E., Kimber, I. (Eds.). New York: Raven. pp. 163-182.

[38] Reyes-Medina, A.J., Pinzon, E.H., Alvarez-Herrera, J.G. 2017. Effect of calcium chloride and refrigeration on the quality and organoleptic characteristics of cape gooseberry (Physalis peruviana L.). Acta Agronomica 66(1): 15-20

[39] Rose, J.K.C., Catalá, C., Gonzalez-Carranza, Z.H., Roberts, J.A. 2003. Cell wall disassembly. In: The plant cell wall, Rose, J.K.C. (ed.). Blackwell Publishing Ltd., Oxford, UK, pp. 264-324.

[40] Sarkar, A.K. 2016. Anthracnose diseases of some common medicinally important fruit plants. Journal of Medicinal Plants Studies 4(3): 233-236.

[41] Sen, F., Karakali, I., Yildiz, M., Kinay, P., Yildiz, F., Iqbal, N. 2001. Storage ability of Satsuma as affected by preharvest treaments. Acta Horticultural (ISHS) 553: 77 78.

[42] Sharma, R.M., Singh, R.R. 2000. Harvesting, postharvest handling and physiology of fruits and vegetables. In: Postharvest technology of fruits and vegetables. Verma, L.R., Joshi, V.K. (eds), Indus Publishing Co., New Delhi, India, pp. 94-147.

[43] Sivakumar, D., Hewarathgamagae, N.K., Wijeratnam, R.S.W., Wijesundera, R.L.C. 2002. Effect of ammonium carbonate and sodium bicarbonate on anthracnose of papaya. Phytoparasitica 30(5): 486-492.

[44] Sohail, M., Ayub, M., Khalil, S.A., Zeb, A., Ullah, F., Afridi, S.R., Ullah, R. 2015. Effect of calcium chloride treatment on post harvest quality of peach fruit during cold storage. International Food Research Journal 22(6): 2225-2229.

[45] Stosic, S., Stojanovic, S., Milosavjevic, A., Dolovac, E.P., Zivkovic, S. 2014. Effect of calcium salts on postharvest fungal pathogens in vitro. Plant Protection 65(1): 40-46.

[46] Talibi, I., Askarne, L., Boubaker, H., Boudyach, E.H., Msanda, F., Saadi, B., Aoumar, A.A.B. 2011. Antifungal activity of some Moroccan plants against Geotrichum candidum, the causal agent of postharvest citrus sour rot. Journal of Crop Protection 35: 41-46.

[47] Thanh, L.H., Tam, N.K.B., Nga, V.T., Thuy, H.T., Van, T.H., Son, H.T., Quynh, N.N., Nga, N.T.H. 2016. Study on the possibility of using microorganisms as biological control fungal pathogens Neoscytalidium dimidiatum causing disease of brown spots on the dragon fruit. Journal of Vietnamese Environment 8(1): 41-44.

[48] Turmanidze, T., Gulua, L., Jgenti, M., Wicker, L. 2016. Effect of calcium chloride treatments on quality char- 
acteristics of blackberry fruit during storage. International Journal of Food and Allied Sciences 2(2): 36-61.

[49] Uthaibutra, J., Saenghn, K., Sornsrivichai, J., Kumpoun, W., Sardsud, V. 1998. Effects of fruit position and preharvest calcicum dips on "Nam Doc Mai" mango fruit quality. In: Disease control and storage life extension in fruit. Coates, L.M., Hofman, P.J., Johnson, G.I. Canberra, ACIAR Proceedings 81: 27-30.

[50] Valero, D., Martínez-Romero, D., Serrano, M., Riquelme, F. 1998. Influence of postharvest treatment with putrescine and calcium on endogenous polyamines, firmness, and abscisic acid in lemon (Citrus limon L. Burn cv. Verna). Journal of Agricultural and
Food Chemistry 46: 2102-2109.

[51] Xuyen, N.T.M. 2012. Diagnosis of post-harvest fungal pathogens on orange cv. Sanh (Citrus nobilis var. typica Hassk) and mandarin cv. Duong (Citrus reticulata Blanco). Thesis on Plant Protection. Can Tho University. $55 p$.

[52] Yu, T., Yu, C., Chen, F., Sheng, K., Zhou, T., Zunun, M., Abudu, O., Yang, S. 2012. Integrated control of blue mold in pear fruit by combined application of chitosan, a biocontrol yeast and calcium chloride. Journal of Postharvest Biology and Technology 69: 49-53. 